Gut, 1989, 30, 425-429

Leading article

\title{
Hormonal control of gastric and colorectal cancer in man
}

Hormonal control of human cancer was first used therapeutically by Beatson in 1895 when he reported response of a massive breast tumour after bilateral salpingo-oophorectomy.' Apart from breast cancer several other tumours are now successfully treated with hormones. It has only recently been realised that gut tumours may be under hormonal control. ${ }^{2-5}$ Many hormones may affect the growth of gastric and colorectal cancer but significant progress has been made in the area of sex steroids and gastrin. Gastric and colorectal cancer account for over 30000 deaths each year in the United Kingdom - over $20 \%$ of all cancer deaths.

\section{Sex steroids}

Gender and parity have been clearly shown to affect incidence and survival in colorectal cancer. The frequency of bowel cancer is increased in nuns ${ }^{6}$ and increasing parity decreases the risk, especially of right sided colonic tumours. ${ }^{78}$ There is an increased incidence of bowel cancer in women with cancer of the breast or reproductive tract. ${ }^{y}$ Whilst changes in bile salt metabolism which persist after pregnancy may affect the incidence of bowel cancer, why should this affect survival? The overall prognosis in bowel cancer is better in women, ${ }^{10}$ and especially in the parous, " so do oestrogens have a protective effect? ${ }^{12}$ Oestrogen receptors (OR) have been reported in human large bowel cancers ${ }^{1 .-16}$ and it may well be that oestrogens inhibit growth of OR + ve colorectal tumours. ${ }^{17}$

The effect of androgens has been studied in animal models. In some strains of rats castration can diminish the risk of carcinogen induced bowel cancer. ${ }^{17}$ is Androgen receptors are present on human colorectal tumours $^{13}{ }^{19-22}$ and changes in androgen concentrations produced by dihydrotestosterone or antiandrogens have led to inhibition and stimulation of experimental tumours.

The relationship of gender to the incidence of gastric cancer is well known and oestrogen receptors on human gastric cancer have been reported by several authors. Initially it was thought that few tumours were OR + ve but using immunohistochemical techniques a higher + ve rate is found..$^{23-25} \mathrm{We}$ recently studied OR status in 100 patients with gastric cancer by an immunohistochemical technique using ERD5 (Amersham) which is a monoclonal antibody directed against a $29 \mathrm{Kda}$ protein found in close association with the oestrogen receptor and found $52 \%$ to be positive. ${ }^{26}$ Whilst ERD5 status correlates well with OR status by classical biochemical techniques in breast cancer, the relationship in gastric and colorectal cancer is not known. 
Early clinical results from Japan suggested a survival benefit in tamoxifen treated patients with gastric cancer but the study was small, historical controls were used and patients received chemotherapy. ${ }^{27} \mathrm{We}$ randomised 100 patients to receive tamoxifen or act as untreated controls - no benefit in length of survival was seen but ERD5 status was prognostic. Not only did ERD5 positive patients survive for a shorter time, but if treated with tamoxifen they survived for a significantly shorter time than untreated controls. ERD5 negative patients had a longer survival and tamoxifen did not significantly affect prognosis. We have therefore investigated the effect of oestrogens and tamoxifen on gastric cancer cell lines in vitro and found that oestrogen and tamoxifen stimulate growth. ${ }^{28}$ Hormonal manipulation may thus still benefit gastric cancer patients, but treatment aimed at decreasing circulating oestrogen rather than OR antagonists should perhaps be considered. In Japan some surgeons recommend oophorectomy in premenopausal females with gastric cancer but there are as yet no hard data to support such a policy.

\section{Gastrin}

Gastrin stimulates growth of normal gastric and colonic mucosa. Some gastric and colorectal cancer cell lines are stimulated by exogenous gastrin in in vitro culture ${ }^{29-32}$ and the growth of xenografts can also be increased..$^{32-36}$ Human primary gastric and colorectal cancer cells have gastrin receptors ${ }^{37-38}$ and respond to gastrin in early in vitro culture. ${ }^{39-40}$ Intracellular gastrin has been demonstrated in tumour cells by immunohistochemistry ${ }^{41}$ and we have recently shown that a gastrin like substance (which is recognised by an antigastrin antibody and is capable of stimulating growth) is produced by human gastric and colorectal cancer cells in early and prolonged in vitro culture. $^{42}$

It seems that autocrine status can be ascribed to gastrin in gastric and colorectal cancer in man. Agents which may prevent the stimulation by exogenous gastrin, or interfere with intracellular gastrin production, release and binding are under investigation. Regression of an 'autocrine' human gastric cancer xenograft has been reported with two compounds..$^{4.24}$

ANTIGASTRIN THERAPY?

There are three categories of agent which may be useful in modifying the trophic effect of gastrin on cancer cell growth:

GASTRIN RECEPTOR ANTAGONIST

Only one gastrin receptor antagonist is available clinically at present. This compound, proglumide, has been widely used in Europe and Japan for the treatment of duodenal ulcer. Proglumide has been shown to inhibit stimulation of cancer cell lines by gastrin in vitro and in vivo..$^{4.45} \mathrm{We}$ are doing clinical studies in gastric and colorectal cancer with proglumide but it is too early to assess results. Proglumide is a relatively weak receptor antagonist but much more potent and specific gastrin receptor antagonists already exist and hopefully will become available for clinical investigations. 
gastric and colorectal cancer xenografts in experimental animals. ${ }^{44-47}$ The mechanism of this effect is uncertain but is probably not caused by decreased serum gastrin concentrations and may be mediated by somatostatin receptors.

\section{PROSTAGLANDINS}

Some prostaglandin compounds affect metabolism of gastrin in man. Enprostil, an $\mathrm{E}_{2}$ prostaglandin derivative, affects postprandial release of gastrin. Enprostil significantly slows in vivo growth of some cancer cell lines which respond to gastrin. Gastric (MKN45) ${ }^{43}$ and colorectal (MC26) ${ }^{48}$ cancers respond but serum gastrin concentrations are only transiently affected. It is not yet known whether other prostaglandin compounds have similar actions.

There is now considerable evidence to support the belief that human gastric and colorectal cancers are under hormonal control. Encouraging results have been seen in in vitro and animal experiments with compounds which interfere with this process. Whether such preliminary results can be translated into real benefit to patients with gastric and colorectal cancer is the challenge for the future.

Department of Surgery,

D L MORRIS, S A WATSON, L G DURRANT, AND J D HARRISON

University Hospital,

Nottingham

References

1 Beatson GT. On the treatment of inoperable cases of carcinoma of the mamma. Suggestions for a new method of treatment with illustrative cases. Lancet 1896; ii: 104-7.

2 Townsend CM, Singh P. Thompson JC. Gastrointestinal hormones and gastrointestinal and pancreatic carcinomas. Gastroenterology 1986; 91: 1002-6.

3 Townsend CM, Beauchamp RD, Singh P, Thompson JC. Growth factors and intestinal neoplasms. Am J Surg 1988; 155: 525-36.

4 Lamers CBHW, Jansen JBMJ. Role of gastrin and cholecystokinin in tumours of the gastrointestinal tract. Eur J Cancer Clin Oncol 1988; 24: 267-73.

5 Tutton PJM, Barkla DH. Steroid hormones as regulators of normal and neoplastic intestinal epithelial cells (review). Anticancer Res 1988; 8: 451-6.

6 Fraumeni JF, Lloyd JW. Smith EM, Wagoner JK. Cancer mortality among nuns: role of marital status in etiology of neoplastic disease in women. $J$ Natl Cancer Inst 1969; 42: 455-8.

7 Weiss NS, Dalling JR, Chow WH. Incidence of cancer of the large bowel in women in relation to reproductive and hormonal factors. $J$ Natl Cancer Inst 1981; 67: 57-60.

8 Potter JD, McMichael AJ. Large bowel cancer in women in relation to reproductive and hormonal factors. J Natl Cancer Inst 1983; 71: 701-9.

9 Schoenberg BS, Greenberg RA, Eisenberg H. Occurrence of certain multiple primary cancers in females. $J$ Natl Cancer Inst 1969; 43: 15-32.

10 Goodwin JD, Brown CC. Some prognostic factors in survival of patients with cancer of the colon and rectum. J Chronic Dis 1975; 28: 441-54.

11 Koch M, McPherson TA, Egedahl RD. Effect of sex and reproductive history on the survival of patients with colorectal cancer. J Chronic Dis 1982; 35: 69-72.

12 McMichael AJ, Potter JD. Reproduction, endogenous and exogenous sex hormones, and colon cancer: a review and hypothesis. J Natl Cancer Inst 1980; 65: 1201-7.

13 Alfor TC, Do H-M. Geelhood GW. Tsangari N, Lippman ME. Steroid hormone receptors in human colon cancers. Cancer 1979; 43: 980-4.

14 Whu N, Cai X, Wu L. Determination of estrogen receptor in human colon cancer tissue with labelled fluorescence estradiol (fluorescein isothiocyanate). Chin Med J 1981; 94: 607-10.

15 Sica V. Contieri E, Nola E. Bova R. Papaleo G, Pinea GA. Estrogen and progesterone binding proteins in human colorectal cancer. A preliminary characterisation of estradiol receptor. Tumori 1981; 67: 307-14.

16 Odagiri E, Jibiki K. Demora R, et al. Steroid receptors and the distribution of IR-carino embryonic antigen in colon cancer. Dis Colon Rectum 1984; 27: 787-91. 
17 Izbicki JR, Somitz R, Kamran D. Izbicki W. Androgens as promoters of colon carcinogenesis. Cancer Detect Prev 1983; 6: 355-62.

18 Moon RC. Fricks CM. Influence of gonadal hormones and age on 1.2 demethylhydrazineinduced colon carcinogenesis. Cancer 1977: 40: 25()2-8.

19 Sani B. Banerjec CK. Peckham JC. The presence of binding proteins for retinoic acid and dihydrotestosterone in murine and human colon tumours. Cancer 1980; 46: 2321-429.

20 Stebbings WSZ, Farthing MJG, Vinson GP. Wood RFM. Do sex hormones affect colorectal cancer? [Letter]. Br Med J 1985; 291: 138.

21 Sani BP. Banerjee CK, Brockman RW. Biochemical markers in colon tumorigenesis: retinoic acid and dihydrotestosterone binding protein. Cancer Tect Prev 1981: 4: 223-9.

22 d'Istria M. Fasano S. Catuogno F. et al. Androgen and progesterone receptors in colonic and rectal cancers. Dis Colon Rectum 1986; 29: 263-5.

23 Tokunaga A. Nishi K. Matsukura N, et al. Estrogen and progesterone receptors in gastric cancer. Cancer 1986; 57: 1376-9.

24 Sica V, Contieri E, Nola E, et al. Estradiol and progesterone receptors in malignant gastrointestinal tumours. Cancer Res 1984; 44: 4670-4.

25 Nishi K. Kunaga A, Shimizu Y, et al. Immunohistochemical study of intracellulor estradiol in human gastric cancer. Cancer 1987; 59: 1328-32.

26 Harrison JD, Morris DL, Ellis IO, Jones JA, Jackson I. A randomised controlled study of adjuvant tamoxifen in the treatment of gastric carcinoma [Abstract]. Br J Surg. 1987; 74: A1143.

27 Kitaoka H. Sex hormone dependency and endocrine therapy for patients with diffuse carcinoma of the stomach. Gan Tokagaku Ryoho 1983; 10: 2453-60.

28 Harrison JD, Watson SA. Ellis IO, Morris DL. Cell kinetic study of the effects of oestradiol and oestramustine on gastrointestinal cell lines [Abstract]. Gut 1988; 10: A1479.

29 Kobori O, Vuillot MT. Martin F. Growth response of rat stomach cancer cells to gastroentero-pancreatic hormones. Int J Cancer 1982; 30: 6.5-7.

30 Ochiai A. Yasui W. Tahara E. Growth promoting effect of gastrin on human gastric carcinoma cell line TMK-1 Jpn J Cancer Res 1985; 76: 1064-71.

31 McRac LJ, Kieng PA, Catina JJ. Role of gastrin and gastrin receptors in the growth of human colon carcinoma cells. J Cell Biol 1986; 103: 220.

32 Sirinek KR, Levine BA, Moyer MP. Pentagastrin stimulates in vitro growth of normal and malignant human colon epithelial cells. Am J Surg 1985; 149: 35-9.

33 Yasui W. Sumiyoshi H. Ochiai T. Tahara E. Cholecystokinin inhibition of tumour growth and gastrin stimulated cyclic adenosine $3^{\prime} 5^{\prime}$ monophosphate metabolism in human gastric cancer in nude mice. Cancer Res 1986; 46: 740-3.

34 Ohkura H. Hanafusa K. Marayama K. Kitoaka H. Watanabe S, Kameya T. Gastrin enhanced tumour growth of a xenotransplantable human gastric carcinoma in nude mice. Jpn J Clin Oncol 1980; 10: 255-61.

35 Winsett OE, Townsend CM, Glass EJ, Thompson JC. Gastrin stimulates growth of colon cancer. Ann Surg 1983; 302: 303-8.

36 Sumiyoshi H. Yasui W. Ochiai A. Tahara E. Effects of gastrin on tumour growth and cyclin nucleotide metabolism in xenotransplantable human gastric and colonic carcinomas in nude mice. Cancer Res 1984; 44: 4276-80.

37 Weinstock J, Baldwin GS. Binding of gastrin-17 to human gastric carcinoma cell lines. Cancer Res 1988; 48: 932-7.

38 Rae-Venter B. Simon PM. Townsend CM. Jr. Thompson JC. Gastrin receptors in human colon carcinoma [Abstract]. Gastroenterology 1981; 80: 1256.

39 Moyer MP. Armstrong A. Aust JB, Levine ISA, Sirinek KR. Effects of gastrin, glutamine and somatostatin on the in vitio growth of normal and malignant human gastric mucosal cells. Arch Surg 1986: 121: 285-8.

40 Watson S, Durrant L, Morris DL. Growth promoting action of gastrin on human colonic and gastric tumour cells cultured in vitro. Br J Surg 1988; 75: 342-5.

41 Tahara E, Ho H. Nakagami K. Shimamoto F. Yamamoto M, Sumi K. Scirrous argyrophil cell carcinoma of the stomach with multiple production of polypeptide hormones, amine. CEA, lysozyme and HCG. Cancer 1982; 49: 1904-15.

42 Watson SA. Durrant LG, Morris DL. Gastrin dependence of human colorectal and gastric tumours [Abstract]. Gut 1988; 29: A738.

43 Morris DL. Watson SA. Harrison JD. Durrant LG. Comparison between the effect of enprostil and proglumide on a human gastric cancer cell line grown both in vitro and as a xenograft [Abstract]. Gut 1988; 29: A737.

44 Morris DL, Watson SA. Harrison JD, Durrant LG. Somatostatin (SMS201.995) reduces growth of human gastric cancer (MKN45) xenografts [Abstract]. Gut 1988: 29: A 1477. 
45 Beuchamp RD, Townsend CM, Singh P, Glass EJ, Thompson JC. Proglumide a gastrin receptor antagonist, inhibits growth of colon cancer and enhanced survival in mice. Ann Surg 1983; 302: 303-8.

46 Singh P, Le S, Townsend CM, Beuchamp RD, Laridjani A, Thompson JC. A long acting somatostatin analog and proglumide inhibit the trophic and gastrin receptor regulatory effects of pentagastrin on mouse colon cancer cells in vivo. Gastroenterology 1986; 90: 1636.

47 Smith JP, Solomon TE. Effects of gastrin, proglumide and somatostatin on growth of human colon cancer. Gastroenterology 1988; 95: 1541-6.

48 Hurlbut SC, Trudel JL, Upp JR, et al. Enprostil inhibits the growth of a mouse colon cancer (MC26) that possesses gastrin receptors. Gastroenterology 1988; 94: A197. 